\title{
Contested Namesakes: East Berlin School Names under Communism and in Reunified Germany
}

\section{Catberine Plum}

Within weeks and months of the fall of the Berlin Wall in November 1989, numerous busts and portraits of school namesakes disappeared from the foyers, hallways, and "tradition rooms" (Traditionszimmer) of East Berlin schools and were relegated to trash bins. In 1990 municipal authorities formalized this spontaneous purge of school identities by eliminating the names of all schools in eastern Berlin. Over the course of the 1990s administrators, teachers, and students in the newly restructured schools began to discuss a wide range of new school identities.

Revolutionary movements often change the names of streets and public buildings and institutions. The renaming of primary and secondary schools at this historical juncture provides a unique vantage point for examining what the democratic turning point of 1989 (Wende) meant to schools and neighborhood communities in practical terms. In this comparative study I first ask what types of names did schools acquire during the forty years of communist rule, and how do these names differ from the choices made after the Wende? Who suggested the names and who had the power to grant schools new identities under each regime? Finally, how have schools celebrated the conferral of the name and what sort of traditions have developed which enable students and teachers to remember and reflect upon the school's namesake? My research reveals that in both the German Democratic Republic (GDR) and in contemporary eastern Berlin, school policy on name conferral was not the result of a simple top-down, decision-making apparatus and instead relied heavily upon the initiative of personnel at the school level. While the examples in this essay are from, East Berlin, my conclusions point

Catherine Plum is an assistant professor of history at Western New England College. She recently completed a Ph.D. at the University of Wisconsin-Madison. This article stems from research connected to her doctoral thesis which is entitled "Antifascism and the Historical Identity of East German Youth, 1961-1989" She would like to express her sincere thanks to the teachers and administrators who consented to be interviewed for this project.

History of Education Quarterly $\quad$ Vol. $45 \quad$ No. $4 \quad$ Winter 2005 
to the historical identity and cultural values promoted more generally in eastern German school districts under communism and after 1989. Oral history interviews inform this study along with documents from the German federal archives and school archives.

When one examines the conferral of names under communist rule between 1949 and 1989, patterns emerge with respect to the timing of applications for honorary names. ${ }^{1}$ School principals frequently petitioned for a concrete identity when a new school was founded or when it was transformed from one type of educational institution to another. Thus some of the first schools to assume names were new schools founded during the 1950s and schools that the Ministry of People's Education (Ministerium für Volksbildung) transformed from traditional elementary and secondary schools (Grundscbulen and Oberscbulen) to ten-year polytechnic schools (Polytechnische Oberschulen or POS) and socialist college-preparatory schools (Erweitere Oberschulen or EOS). Increasingly and certainly by the mid 1970s, many school administrators on the district, regional, and national levels expected schools to have names to supplement their nondescriptive numbers as a form of identification and as a means to instill political values. However, principals' interpretations of the expectations and priorities of the districtlevel school administration varied.

Compared to the other fourteen provinces within East Germany, Berlin schools were not necessarily progressive in terms of the speed with which they applied for new identities. Schools in Berlin began to apply for names in large numbers in the mid-1970s. Whereas only eleven schools in the district of Berlin-Prenzlauer Berg obtained a name between 1960 and 1975 , over a period of only four years, from 1976-1979, nineteen additional schools successfully petitioned for a namesake. ${ }^{2}$ By 1988 all forty-five of the POS and EOS schools in this district possessed honorary names. ${ }^{3}$ Nonetheless, there were some schools in East Berlin that still did not have names by the time of the Wende. Some of the schools without names had just been founded in the late 1980s to accommodate young families in developing urban suburbs, such as Marzahn and Hellersdorf.

'It is important to note that in addition to schools and youth group chapters, it was also common for other institutions to petition for namesakes such as factories, military units, nursing homes, youth centers, athletic clubs and chapters of the Democratic Women's Association of Germany (DFD). See Peter Joachim Lapp, Traditionspflege in der DDR (Berlin: Verlag Gebr. Holzapfel, 1988), 20-30.

${ }^{2}$ Klaus Grosinski and Mathias Schreyer, Schulen in Prenzlauer Berg Zablen, Fakten und Personen: Materialien zur Schulgescbicbte des Bezirks Prenzlauer Berg von Berlin (Berlin: Moritzdruck, 1993), 92-95.

${ }^{3}$ Klaus Grosinski, Scbulen, Scbüler, Scbulgebäude im Bezirk Prenzlauer Berg von Berlin: Eine Handreichung zur Erforschung des Bezirks (Berlin: Prenzlauer Berg für Heimatgeschichte und Stadtkultur, 1998), 99-100. 
The most common names were those of dead communist revolutionaries, and indeed a majority of the namesakes were also veterans of the struggle against fascism. ${ }^{4}$ Thus typical male namesakes included famous leftist politicians like August Bebel and Karl Liebknecht and antifascists such as Ernst Thälmann, Artur Becker, Hans Beimler, and Hanno Günther. By 1974 there were at least 112 schools named after Ernst Thälmann, the leader of the German Communist Party in 1933 who the Nazis murdered. ${ }^{5} \mathrm{~A}$ minority of schools petitioned to be named after female personalities, such as Rosa Luxemburg and Anna Seghers as well as antifascist partisan fighter Katja Niederkirchner and her Soviet counterpart Soja Kosmodemjanskaja. However, not all of the historical personalities had communist backgrounds or clear leftist sensibilities; several schools in East Germany were named after Anne Frank and White Rose student resistors Hans and Sophie Scholl. ${ }^{6}$ By 1975 at least thirty-seven schools in East Germany were named after one or more of the Scholl siblings. ' In the mid-to-late 1980s, some of the newly founded schools in outlying regions of East Berlin took on the names of more contemporary international personalities such as Ernesto Che Guevara and Soviet cosmonaut Vladimir Komarov. ${ }^{8}$ Nevertheless, the vast majority of namesakes focused attention on the communist, antifascist resistance movement carried out by German and international activists, partisan fighters, and Soviet military leaders.

The commemoration of communist, antifascist traditions served several purposes. First of all, East German leaders linked the struggle against fascism with the history of the workers' movement to legitimate the government and to establish a sense of continuity between the new socialist regime and German history and cultural traditions. The creation of both an historical continuity and a new sense of national identity were crucial in light of East Germany's artificial borders and the rapid establishment of new political institutions competing with West German models. Indeed, the East German example supports Anthony D. Smith's argument that in times of rapid social

'Long before the foundation of the German Democratic Republic in 1949, there were German cultural traditions related to the naming of primary and secondary schools. Prior to and during the Weimar Republic, schools commonly assumed the names of political leaders or personalities from German cultural and intellectual history.

s“Auswahl der Oberschulen und PF, die den Namen 'E. Thälmann' tragen," Stiftung Archiv der Parteien und Massenorganisationen der DDR at the Bundesarchiv [hereafter SAMPO-BArch], DY 24/14.010.

${ }^{6}$ Partial lists of the names of schools and their Pionienfreundschaffen and FDF Grundorganisationen from the 1970s can be found in the following FDJ files at the SAMPO-BArch, Berlin DY 24/14.007-14.010.

'Ibid.

${ }^{8}$ Interviews with two teachers who worked in Marzahn in the late 1980s, interviewed by the author, Berlin, 9 October 2001 and 30 September 2001. Tape-recorded copies of all interviews used in this article are in the possession of the author. 
change, the tendency is ever stronger to mask radicalism with a "veil of tradition and continuity" usually stemming from a perceived national past. ${ }^{9}$ Additionally, a focus on Soviet antifascist heroes helped to form the official narrative of the heroic deeds of the Soviet Union during the war and its aftermath. This official narrative remained important given the continued presence of the Red Army in postwar East Germany, Soviet influence, and persistent Cold War divisions.

The Ministry of People's Education considered namesake campaigns to be a tool in promoting both an sense of a historical identity and an awareness of the duties of contemporary citizens. In a 1978 speech given at a workshop for youth group functionaries and resistance fighters, a spokesperson explained the political goals behind the namesake movement: "From our past experience with political education, we have learned that historical and contemporary events are always linked with names....Young people personally experience and comprehend that which is exemplary, the heroic class struggle of the past, when they strive for the name of a revolutionary fighter for their organization ...."

In addition to cultivating a sense of the historic role of working-class revolutionaries, students were asked to imagine what kind of a GDR citizen their deceased namesake would have been. A Berlin member of the Committee of Antifascist Resistance Fighters made this point in a 1984 letter to tenth graders at a school in Seyda: "Keep in mind that it [the application for a namesake] is not only concerned with thinking about the antifascist resistance fighter whose life was lost in the struggle. On the contrary, one can best honor him when one acts as he would today in the fight for freedom and the strengthening of our socialist republic given the worsening international situation. In your case, this means studying diligently, supporting our friendship with the Soviet Union and being ready to defend our socialist homeland."

School administrators and members of the Committee of Antifascist Resistance Fighters found they needed to focus attention not on the selection of well-known communist antifascists, but rather on the choice of a Soviet revolutionary figure or a less famous, but local communist antifascist figure. Selections made from the latter two categories expanded opportunities for student interaction with local and international history to supplement the national narrative found in history textbooks. Few schools adopted Soviet

"Anthony D. Smith, “The Nation: Invented, Imagined, Reconstructed?" Millenium 20 (1991): 356.

${ }^{10}$ Untitled speech, Zentrale Erfahrungsaustausch der Zentralleitung der KAW der DDR und der Zentralrat der FDJ zur Wahrung und Pflege revolutionärer Traditionen in der Arbeiterjugend, Leipzig, June 1978, SAPMO-BArch DY 24/10.522, 13.

"Stellvertretener Vorsitzender der Sektion ehemaliger Spanienkämpfer der KAW Berlin, letter to a tenth grade class at POS Seyda, 20 February 1984, SAPMO-BArch DY $57 / \mathrm{K} 87 / 1$. 
names. One disadvantage associated with Soviet historical figures was the difficulty school children might have pronouncing the name. For example, students and residents of Weißensee often referred to the Swierczewski Schule as simply the 8. POS instead of using the official Russian name. ${ }^{12}$

After the restructuring of the school system in $1991,{ }^{13}$ administrators encouraged schools to discuss and petition for new namesakes. Schools soon began to apply for a wide range of namesakes including the names of pedagogues, social activists, artists, and scientists such as Clara Grunwald, Martin Luther King Jr., Käthe Kollwitz and Max Planck. While some schools took on the names of political figures like Ludwig Erhard, other schools chose not to select individuals associated with political parties or offices. Additionally, some Grundschulen for the elementary grades took on fictional names or names of personalities involved in issues of interest to children. Thus, a school in Prenzlauer Berg acquired the name Stummelpeter, a children's literary figure, and a school in Hellersdorf selected Daphne Sheldrick as its namesake. The elementary school students of the SheldrickGrundschule continue to demonstrate an interest in Sheldrick's work as an animal activist who works in Kenya caring for baby elephants whose mothers had died or been killed by hunters. ${ }^{14}$

Interviews with contemporary school principals suggest an interest in Anglo-American names such as Martin Luther King and John Lennon, but also some parents voiced their preference for more well-known German or local personalities, with which the school population would be more familiar. ${ }^{15}$ In the case of the Martin Luther King Gesamtschule in Prenzlauer Berg, some advocates of this name drew a correlation between King's advancement of nonviolent protest and the nature of the freedom movement in East Germany during the final weeks of the regime's existence. A representative from the Berlin Historical Association e.V. highlighted this parallel in a commemorative booklet for the name conferral celebration in 1996: "King's belief that social-political conflict can be resolved without violence was unshakeable.... It was the spirit of King which accompanied millions of courageous Germans through the streets of Leipzig and Berlin, as they declared unequivocally to their nation's leaders, 'We are the people."'16

\section{1.}

${ }^{12}$ Interview with Joachim Müncheberg, interviewed by the author, Berlin, 13 December

${ }^{13}$ Bezirksamt Mitte von Berlin, Schulamt, Schulen in Berlin-Mitte (Berlin: Druckhaus Schöneweide, 1993), 8.

${ }^{14}$ Interview with a teacher at the Sheldrick Schule, interviewed by the author, Berlin, 16 October 2001.

${ }^{15}$ School principals Jochen Pfeifer and Dr. E. Heerwig, interviewed by the author, Berlin, 24 October 2001 and 7 November 2001 respectively.

${ }^{16}$ Dr. Morton Nirenberg, "Grußwort der Berlin Historical Association e.V. an die Martin-Luther-King-Oberschule Berlin - Prenzlauer Berg," in the program booklet, "MartinLuther-King-Oberschule (Gesamtschule)," ed. R. Peters, Dr. E. Heerwig and B. Einbrenner (Berlin: 30 May 1996), 17. 
If one examines names chosen in the early 1990s, it is clear that some schools in eastern Berlin successfully campaigned to regain their former GDR namesake. ${ }^{17}$ The case of the Hans-und-Hilde-Coppi-Gymnasium in Berlin-Lichtenberg demonstrates the degree of controversy unleashed by discussions of christening schools after their former antifascist namesake. During the GDR, the school had acquired the name Hans Coppi after a young worker and communist from Berlin who became involved with the Rote Kapelle resistance circle. ${ }^{18}$ Although Hans Coppi and his wife Hilde were part of a group that demonstrated diverse political standpoints, some observers were not in favor of renaming the school after the couple based on their political affiliation. West German history teacher Peter Klepper, working temporarily at the school, advocated instead the writer and chemist Robert Havemann, a communist who resisted National Socialism, but one who also could be termed anti-Stalinist based on his writings during the GDR. Klepper feared that one of the primary disadvantages with the name "Coppi" was that observers might assume that the "old spirit," a spirit of Soviet influence, still prevailed in the school, which is located in an area with a large number of former Stasi employees and informants. ${ }^{19}$

In the end a committee made up of teachers, students, and parents voted in favor of taking on the names Hans and Hilde Coppi after another school took the name Robert Havemann. ${ }^{20}$ Advocates of the name Coppi commented on the democratic process used to select the name. Indeed principal Joachim Müncheberg described the discussion process as democracy "live," using an English word to capture a sense of the free-flowing discussion and debate in which the majority eventually prevailed. ${ }^{21}$ For many individuals involved with this decision, the physical act of discussing and voting on the school namesake came to symbolize their own embrace of and ability to practice democratic principles and were made possible by the Wende.

In contrast to the experience of the Hans-und-Hilde-Coppi-Gymnasium, the selection of a namesake in the GDR could not be termed "democratic" due to official expectations and the process of name selection. One might assume, as some former GDR citizens do, that administrators from above essentially selected a school's name. However, in many documented cases the idea for the school's name came from the school itself often from the

${ }^{17 G r o s i n s k i, ~ S c h u l e n, ~ S c b u ̈ l e r, ~ S c b u l g e b a ̈ u d e, ~ 101-102 . ~}$

${ }^{18}$ Hans Coppi, "Rote Kapelle" in Lezikon des deutschen Widerstandes ed. Wolfgang Benz and Walter H. Pehle (Frankfurt am Main: S. Fischer Verlag, 1994), 281-4.

${ }^{19}$ Claudia Belting, "Der neue Name und der 'alte Geist' Schüler, Lehrer und Eltern streiten darüber, wie das 6. Gymnasium heißen soll," Berliner Morgenpost, 19 January 1993, 29.

${ }^{20}$ Projektgruppe "Schulchronik," "Chronik der 6. OG Hans-und-Hilde-Coppi," (Berlin, 16 July 2001), 3. Copies of the chronicle are available at the school.

"Ibid. 
school principal or a teacher and less frequently from a parent or student. ${ }^{22}$ For example, an elementary school teacher at the 21. POS in BerlinFriedrichshain was the first to suggest the name Herbert Baum for the school. ${ }^{23}$ There are also at least two cases, the Cäsar-Horn-Schule in Pankow and the Bernhard-Koenen-Schule in Köpenick, where students and parents in Berlin were involved in the discussion of names during the $1970 \mathrm{~s}^{24}$ However not all teachers, much less parents and students, were asked their opinions. In her memoirs former science teacher Sabine Hadicke recalled a teachers' meeting in the 1980 s where she was simply informed that the new school would apply for the name Wilhelm Pieck, the first president of the GDR. ${ }^{25}$ Schools also tended to petition for names that they felt had a solid chance of being approved by district-level school administrators. Hence the choice of regime-friendly names was often attained with little pressure from administrators at the district and provincial levels.

In contemporary East Berlin, the selection process tends to be more uniform and democratic in nature. In the cases examined for this study, schools included students as well as teachers and parents in brainstorming sessions. Moreover, in the case of the John-Lennon-Gymnasium in BerlinMitte, students exercised a considerable sway over their parents who favored naming the school after the famous social democratic leader August Bebel. ${ }^{26}$ The case of the John-Lennon-Gynasium provides a striking example of a controversial name campaign that reveals the power relationships between students and teachers on the one hand and school employees and the municipal school board (Volksbildungsstadtrat). The music teacher at the school, former GDR rock star Lieselotte Reznicek, originally suggested the name John Lennon. According to Reznicek, the teaching staff became divided over her proposition, and a virtual war (Krieg) broke out. ${ }^{27}$ Some veteran teachers raised their index fingers and warned their pupils that with a diploma carrying the name John Lennon they would have little hope on the job market. In part many teachers were concerned that the school and city councils (Scbulrat and Stadtrat) would simply not approve of the name, given the Beatles' association with drug use. In this way, teachers' reaction

\footnotetext{
${ }^{22}$ Interview with a former teacher who taught in Friedrichshain in the 1970s, interviewed by the author, Berlin, 18 August 2001.

${ }^{23} \mathrm{Ibid}$. Herbert Baum led a group of communist resistance fighters in Berlin, many of whom also had a Jewish background.

${ }^{24}$ Irmgard Klaus, former GDR principal and widow of Cäsar Horne, interviewed by the author, Berlin, 27 September and 3 October 2001; Interview with a former teacher from the Bernhard-Koenen-Schule, interviewed by the author, Berlin, 27 August 2001.

${ }^{25}$ Sabine Hadicke, Lebrjabre: Erinnerungen an den Sozialistischen Alltag Jena: Verlag Neue Literatur, 2000), 134. 14.

${ }^{26}$ Vera Gaserow, “Von Lenin zu Lennon Umbennant.” Die Zeit Nr. 29, 15 July 1994,

"Lieselotte Reznicek, interviewed by the author, Berlin, 25 October 2001.
} 
was not all that different from school administrators and teachers in the GDR who tended to apply for names they felt would likely be approved. Not all students favored the name either. In reaction to the proposal some students expressed their dissatisfaction in the form of graffiti, referring to a potential John Lennon school as a "Scheiß Hippie Schule." ${ }^{128}$ Nonetheless after a period of intense discussion, a school committee sided with the majority of students and approved the name unanimously. ${ }^{29}$ Contrary to the fears of some teachers and observers, the municipal department of education approved the name, and in doing so administrators endorsed a decision that had been made at the school level.

In addition to exploring the process of selecting a namesake, one can also compare how schools conducted their namesake campaigns. To prove their worthiness to take on a namesake, GDR school administrators and teachers identified general successes in their school as well as concrete activities through which their students learned about their future namesake. In terms of school-wide accomplishments, administrators frequently referred to successful sport teams, a large number of children involved in school clubs or receiving a badge for their knowledge of Marxism-Leninism, a significant amount of recyclables collected, or an impressive number of pen pal relationships formed between their students and children in the Soviet Union. Applications for namesakes thus reveal some of the campaigns and activities most highly praised in East German schools that were intended to promote socialist personalities. Additionally, for name campaigns it was common for each grade level to engage in a research project related to their namesake or his or her cause.

In namesake campaigns during the 1990s there was a greater focus on the suitability and advantages of a particular name than on the question of whether or not the students had really earned the right to have their school carry the name through research projects and visual displays on the school's patron. Schools in the former East Berlin still want their students to learn about their namesake, but they often promote a variety of different activities in preparation for the name conferral made possible in part through the diversity of names. For example, in 1996 a school in Prenzlauer Berg applying for the name Martin Luther King, held a day on which students could engage in a specialized course or project of their choice in which they could compose a biography of King in English, sing gospel and AfricanAmerican spiritual music, or learn about topics such as the state of Georgia, cotton, or American cheerleading. ${ }^{30}$

\footnotetext{
${ }^{28}$ Frank Kempe, "Eine Schule für John Lennon," Tagezeitung, 8 July 1994, 28.

${ }^{29}$ Barbara Wiegand, "Lennon statt Bebel: Gymnasium gibt sich neuen Namen," Berliner Morgenpost, 12 July 1994.

${ }^{30}$ R. Peters, Dr. E. Heerwig and B. Einbrenner ed., program booklet, "Martin-LutherKing-Oberschule (Gesamtschule)," (Berlin, 30 May, 1996), 20.
} 
The diversity of patron namesakes has also enabled present-day schools in East Berlin to plan quite creative ceremonies to celebrate the school's christening. In the GDR name conferral ceremonies were rather formal, including the presence of flag-bearing children in their youth group uniforms, marching parades, revolutionary "fighting songs" (Kampflieder), and of course speeches. Contemporary celebrations also tend to have a formal ceremony component that includes speeches, but the music portion of the event may vary substantially as does the content of speeches. For example, at the christening of the Martin-Luther-King-Oberschule in Prenzlauer Berg in June 1996 a "pop choir" performed gospel and spiritual music. ${ }^{31}$ At the John-Lennon-Gymnasium in Mitte, the name conferral ceremony included performances by contemporary school bands. ${ }^{32}$ However, one similarity between GDR-era and contemporary schools is that students' study of and interaction with their namesake's biography and life's work is not intended to end with the name conferral ceremony.

In reunified Germany, schools in eastern Berlin have adopted a combination of new and old traditions and practices to commemorate their honorary namesake in the years that follow. The GDR practice of creating visual displays in memory of the school's honorary name has continued in a muted form in school hallways. At the Hans-und-Hilde-Coppi-Gymnasium there is a sculpture of Coppi in the foyer and a small exhibit that details the couple's resistance against National Socialism. However, the exhibit and sculpture were added as late as July $2001,{ }^{33}$ providing a buffer of temporal distance from the spontaneous purge in 1989-90 of school-sponsored tradition rooms and the intense debates about the school's namesake in the early 1990s. According to the present principal, the school distances itself from GDR practices by choosing not to establish an entire room to their namesake. ${ }^{34}$ The fact that some contemporary traditions are tempered and controlled versions of GDR practices suggests a certain degree of continuity between East German and contemporary forms of tradition that grows out of familiarity and an incomplete rejection of GDR traditions. In other words, not all aspects of GDR name conferral and commemoration are considered formulaic and one-dimensional. Quite often, altered GDR practices are used to promote themes that were not a major focus in many GDR schools. For example, in 1992 a school applying for the name Clara Grunwald constructed an exhibit entitled "The Yellow Star," which explored the experiences of Jews during the Nazi Regime. While students in the GDR learned a little about Nazi persecution of Jews and the Holocaust in their

${ }^{31}$ Ibid, 22.

${ }^{32}$ Kempe, "Eine Schule für John Lennon," 28.

${ }^{33} \mathrm{Julia}$ Wiedemann, "Neue Ausstellung statt roter Ecke; Einweihung einer Hans Coppi Büste in Lichtenberger Gymnasium," Neues Deutscbland, 13 July 2001, 16.

${ }^{34}$ Müncheberg, interview. 
history classes, with the situation improving towards the end of the regime, there were rarely special projects devoted to this theme. ${ }^{35}$

Alongside notable successes in using the namesake as a teaching tool, both GDR and contemporary schools have encountered some difficulties commemorating their school mascots. In the GDR, antifascist veterans and youth group leaders voiced several complaints about the choice of namesakes and the commemorative practices of schools and their youth group chapters. Some noted that all too often schools and youth groups chose well-known antifascists as namesakes, for whom information was widely available, rather than selecting a lesser-known local antifascist. If a school selected a local antifascist it was often possible for the students to meet with commrades and surviving family members of their namesake. At the very end of the GDR, the First Secretary of the Free German Youth organization (FDJ), Eberhard Aurich, noted in a speech to FDJ dignitaries that schools often relied on formal celebrations and ideas instead of formulating their own means of commemoration and engaging in open and critical discussions. Beyond copying a biography from a book and hanging a picture on the wall, students really needed to become engaged in the life and cause of their namesake. ${ }^{36}$ By the end of the 1980s, educators and youth leaders were recognizing some of the inherent problems in antifascist education and commemoration, due in part to students' lack of emotional ties to their namesake and the period in which he or she lived.

In contemporary schools in eastern Berlin, many school namesakes such as John Lennon and Martin Luther King stem from the period since World War II and are associated with movements with which students can readily relate. Nevertheless, not all namesakes are as contemporary, and schools have encountered some problems founding meaningful traditions that inspire their students. Through its charismatic namesake, the JohnLennon-Schule has the opportunity to promote and support students' musical initiatives. The school's 1998 music compact disc from school bands reveals this potentiality, however, according to one teacher, not all school classes are as talented and musically engaged as those that produced the CD. ${ }^{37}$ Teachers at the Mildred-Harnack-Oberschule have experienced a different problem; they feel constricted in that they cannot pursue projects that too closely resemble GDR practices. ${ }^{38}$

\footnotetext{
${ }^{35}$ Invitation, "Namensgebung der Clara-Grunwald-Grundschule am 4. September 1992," Clara-Grunwald-Grundschule Archiv.

${ }^{36}$ Eberhard Aurich, "In der Einheit der Generationen liegt unsere Stärke," "Dokumentation 7'88" Beilage zu Pionierleiter (21/88), 12-13.

${ }^{37}$ Interview with a teacher from the school, interviewed by the author, Berlin, 16 November 2001. 2001.

${ }^{38}$ Interview with Frau Reich, principal, interviewed by the author, Berlin, 15 November
} 
This comparison of school names and namesake commemoration reveals the legacies two distinct school systems sought to and continue to bestow on multiple generations of students in eastern Berlin. Namesake campaigns under communism and in the immediate post-1989 era relied upon the creative energy and initiative of school principals and teachers on the grass-roots level. Without student input, most GDR schools were named after communist revolutionaries and antifascist veterans in particular, resulting in an often one-dimensional view of resistance against National Socialism and political values including socialist conviction, steadfastness, and a willingness to defend socialism through personal sacrifice. Modeling democracy in action, schools in the early to mid 1990s chose a wonderfully diverse assortment of namesakes which reveal a continued interest in the struggle against National Socialism, but also an awareness of key personalities involved in movements against war and violence and in favor of educational reform, racial and sexual equality, and human and animal rights. Despite their inherent imperfections contemporary namesakes have inspired within schools critical discussion along with controversy and innovative projects as well as unique challenges. At the same time educators have preserved some GDR commemorative traditions in an altered form revealing an incomplete rejection of select GDR practices which is typical or characteristic of the contemporary educational landscape more broadly. After the rapid rejection of many features of GDR schools, the socialist upbringing of many contemporary teachers continues to affect the color and texture of students' educational experiences in eastern Berlin. 